\title{
Teaching Reform of English Listening and Speaking in China Based on Mobile Micro-Learning
}

\author{
Caiqiao Huo, Baoguo Shen \\ Foreign Language Department, Baoding University, Baoding, China \\ Email: goofyhuo@163.com
}

Received 30 October 2015; accepted 27 November 2015; published 30 November 2015

Copyright (C) 2015 by authors and Scientific Research Publishing Inc.

This work is licensed under the Creative Commons Attribution International License (CC BY). http://creativecommons.org/licenses/by/4.0/

(c) (i)

\section{Abstract}

Mobile micro-learning is an effective form of informal learning which can meet the personalized needs of language learners. In the ultra-video era, micro-video and micro-audio with short vivid contents, consistent with the current people's viewing habits, have become a hot focus. With the development of mobile communication technology, mobile media terminal also shows a trend of diversification, but how to combine micro-learning with micro-video and micro-audio closely, in order to learn English scientifically and effectively for learners, is a major problem. Students are at a learning stage, more eager to experiment with new things, and the mobile media tools are used widely among them. Based on the theory of mobile micro-learning, this study analyzes the advantages of the micro-video and micro-audio, and then focuses on the strategies in making or selecting micro-video and micro-audio. Through the data analysis, the author tries to get information about the actual situation of college students' mobile learning. Based on the current situation, the author chooses to use cell phones which are widely used and easy to operate as the hardware platform. By analyzing and designing video and audio contents, some practical methods are offered. Through the study, the author hopes to help learners practice listening and speaking more effectively, and promote the teaching reform of English listening and speaking in China.

\section{Keywords}

Mobile Micro-Learning, English Listening and Speaking, Teaching Reform

\section{Introduction}

Mobile micro-learning is a new learning theory proposed in recent years, which combines features of mobile 
learning and micro-learning. It means that learners can learn at any location with the use of mobile devices. Micro-learning deals with relatively small learning units and short-term learning activities. Generally, the term "micro-learning" refers to micro-perspectives in the context of learning, education and training. It characterizes as extensiveness and interactivity. Extensiveness means learners can conduct their studies at any place; interactivity means learners and experts can exchanges ideas or discuss problems through the internet. Mobile micro-learning learners are out of the normal classroom environment; their environment may be noisy, so they are easily distracted. Therefore, the design of learning contents must be short and practical. All in all, the characteristics of mobile micro-learning include: fragmented learning time, unlimited learning sites, short and practical learning contents, interactive learning styles. And the specific requirements for English majors are to grasp the basic language skills and to do well in listening, speaking, reading, writing and translation. Good listening and speaking ability is the ability English graduates must have. This paper is based on the theory of micro mobilelearning, combined with the practice of English listening and speaking teaching and put the theory into practice. The author analyzes the problems in listening and speaking teaching and provides some appropriate teaching strategies. With making or selecting interesting micro-audio and micro-video materials, the author hopes language learners can practice more effectively. The results of this research will also enrich the connotation of mobile micro-learning theory.

\section{Research Background}

In other countries, the study of mobile micro-learning is mainly conducted in some developed countries in Europe and North America. Micro-learning based on technology can be traced back to early 1960s, the originator of the micro-teaching in Stanford University. Theo Hug is one of the scholars who gave the definition of micro-learning. He believes that micro-learning is a process during which learners deal with small learning units and focus on learning in a short time (Hug, 2005: p. 7). Since 2005, the University of Innsbruck in Australia sponsors and holds an international conference on micro-learning every year.

In China, Chen Weiwei and Li Yi from Nanjing Normal University have studied the contents and structure of the mobile micro-learning and proposed a series of problems during mobile micro-learning in the future (Chen, 2008: p. 16). Ren Haifeng and Zhao Jun from Harbin Deqiang Business College has analyzed the current research situation about mobile learning and noted that domestic research on mobile learning has just started and there is still instability in the learning system, lack of resources which also shows that there is a wider space for development on mobile learning (Ren \& Zhao, 2010: p. 95). Zhang Hao Feng and Zhu Ximei from Henan Normal University studied the situation about the application of mobile micro-learning in distance education, and has noted that the mobile micro-learning learners are not in the normal classroom environment; their environment may be noisy and they are easily distracted. Therefore, learning contents should be designed to be short and must be practical (Zhang \& Zhu, 2011: pp. 75-76). Hao A Min and Zhang Panfeng from Hebei Normal University has studied the application of mobile micro-learning in teaching English vocabulary and suggested that the micro-video should be designed to meet students' learning taste and stimulate students' interests in learning (Hao \& Zhang, 2013).

\section{Study Design}

\subsection{The Objective of the Study}

This study is guided by mobile micro-learning theory, and focuses on the practical application in English listening and speaking. Mobile devices which are available for the students are used as the platform. The researcher design some micro-video and audio which are suitable for students' psychological characteristics and can stimulate students to learn at any time and any place. During this process, the researcher summarizes the problem, searching or making more learning materials. And revising some teaching strategies and applied the strategies in class. The goal is to solve the problems in improving listening and speaking. The study is conducted as following:

- First, the researcher analyzes the obstacles in listening and speaking;

- Second, investigate the mobile devices available to students;

- Third, analyze the result of learning through mobile devices. 


\subsection{The Subject of the Study}

There are 1500 students from Hebei University and Baoding University involved in this study, including 643 English majors and 857 non-English majors. The participants who answered the IELSMD (investigation on English listening and speaking with mobile devices) questionnaire are sophomores aged from 18 to 21 years old from Foreign languages Department, Economics Department, Chinese Department and Marketing Department. There are totally 1500 copies handed out, with 1470 effective questionnaires being taken back, the recovery rate is $98 \%$. The data is analyzed by Excel.

\subsection{Instruments}

In order to know the electronic devices college students have, learning status with their electronic devices and the obstacles they encounter while practicing English listening and speaking, I made the IELSMD questionnaire. Table 1 lists all the variables in the study.

Table 1. Description of the IELSMD questionnaire.

\begin{tabular}{|c|c|}
\hline Variables & Description \\
\hline Q1. Gender & $\begin{array}{l}\text { A. Female } \\
\text { B. Male }\end{array}$ \\
\hline Q2. Major & $\begin{array}{l}\text { A. Arts } \\
\text { B. Science }\end{array}$ \\
\hline Q3. Age & $\begin{array}{l}\text { A. } 15-17 \\
\text { B. } 18-19 \\
\text { C. } 20-21\end{array}$ \\
\hline Q4. Do you have cell phones or other electronic devices? & $\begin{array}{l}\text { A. Yes } \\
\text { B. No. }\end{array}$ \\
\hline Q5. What are your mobile devices on hand? & $\begin{array}{l}\text { A. Cell phone } \\
\text { B. MP3/MP4/MP5 players } \\
\text { C. Electronic dictionary } \\
\text { D. Laptop } \\
\text { E. Ipad }\end{array}$ \\
\hline Q6. What do you often do on the Internet? & $\begin{array}{l}\text { A. Chat } \\
\text { B. Playing games } \\
\text { C. Studying }\end{array}$ \\
\hline Q7. Do you often study English online? & $\begin{array}{l}\text { A. Often } \\
\text { B. Sometimes } \\
\text { C. Occasionally } \\
\text { D. Never }\end{array}$ \\
\hline $\begin{array}{l}\text { Q8. Do you love watching micro-video on line to practice English } \\
\text { listening and speaking? }\end{array}$ & $\begin{array}{l}\text { A. Love it Very much } \\
\text { B. Love a little } \\
\text { C. don't love at all }\end{array}$ \\
\hline $\begin{array}{l}\text { Q9. Do you love listening to micro-audio on line to practice English } \\
\text { listening and speaking? }\end{array}$ & $\begin{array}{l}\text { A. Love it very much } \\
\text { B. Love a little } \\
\text { C. Don't love at all }\end{array}$ \\
\hline Q10. How long do you prefer the video or audio clip to last? & $\begin{array}{l}\text { A. } 3 \text { - } 5 \text { minutes } \\
\text { B. } 5 \text { - } 10 \text { minutes } \\
\text { C. Longer than } 10 \text { minutes }\end{array}$ \\
\hline \multicolumn{2}{|l|}{ Q11. What do you often do to practice English listening and speaking? } \\
\hline Q12. What kind of materials are you interested in while studying on l & \\
\hline
\end{tabular}




\section{Data Analysis}

\subsection{Various Electronic Devices Students Own}

There are three topics in the questionnaire about the types of electronic devices held by students. According to the survey, cell phone is the most commonly used among students, with one cell phone for each; about 75 percent of students use MP3/MP4/MP5 players; 67 percent of students use electronic dictionaries; 45 percent of the students use laptop; 38 percent of the students use ipad (see Chart 1).

\subsection{Situation of the Students' Learning with the Electronic Devices}

In the statistical results of 1470 valid questionnaires, 100 percent of the students get the access to the Internet with their devices; 98 percent of students conduct online learning; in a variety of learning styles, and 53.21 percent of the students think micro-video can have better effects; 34.79 percent of the students believe that microaudio can improve their English pronunciation and have good effect on improving listening ability; 9.87 percent of the students think the form of learning is not important, and they can take advantage of network resources to learn off their own bat: 2.13 percent of the students never study online (see Chart 2 students learning English listening and speaking online).

\subsection{Result of the Study}

The result shows that there are ten obstacles students often encounter in English listening and speaking. They are listed by descending order of proportion as following: 1) do not understand the meaning of words; 2) can not recognize the learnt words; 3) recognize the words, but don't know the meaning in the material; 4) miss the later sentence while thinking about the former sentence; 5) former obstacles lead to misunderstanding later information; 6) forget the information just heard quickly; 7) do not understand the key information; 8) understand the meaning of every word, but do not understand the overall meaning of discourse; 9) can not keep up with the speaker or are not used to the speaker's accent and intonation; 10) do not understand the cultural context involved in the contents. Table 2 shows the proportion of the ten barriers before and after mobile micro-learning

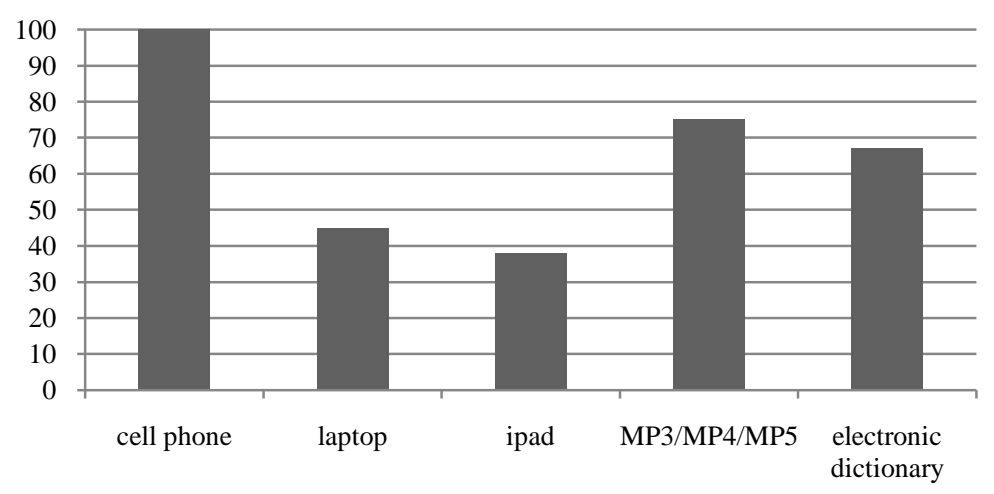

Chart 1. Various electronic devices students own.

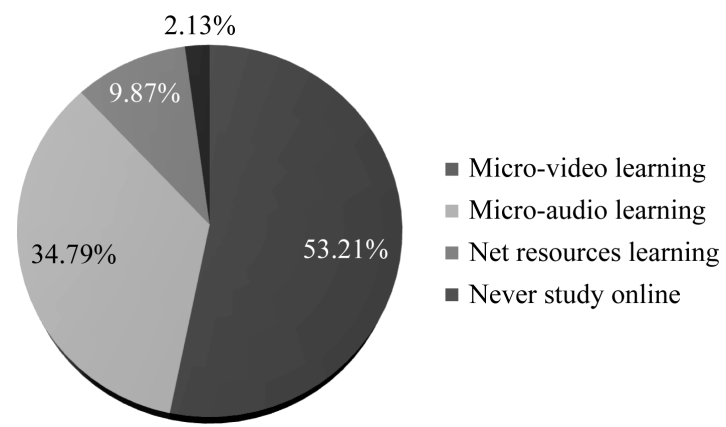

Chart 2. Situation of students' learning with the electronic devices. 
Table 2. Decline in the proportion of the obstacles.

\begin{tabular}{ccccccccccc}
\hline & 1 & 2 & 3 & 4 & 5 & 6 & 7 & 8 & 9 & 10 \\
\hline Pre-training & 100 & 100 & 97.13 & 97.13 & 92.98 & 92.83 & 85.87 & 84.63 & 82.57 & 82.39 \\
Post-training & 40.1 & 34.25 & 21.20 & 22.54 & 17.25 & 11.34 & 7.67 & 23.12 & 12.57 & 68.29 \\
Decline & 59.9 & 65.75 & 75.93 & 74.59 & 75.73 & 81.49 & 78.20 & 61.51 & 70.00 & 14.10 \\
\hline
\end{tabular}

training (Hu, 2015: p. 35). Data analysis shows that after studying through micro-video and micro-audio method, there is a substantial decline in the proportion of the obstacles except the tenth one (see Table 2).

\section{Discussions}

With the development of information technology, many scholars are trying to combine mobile technology with studying. For most English learners in china, English listening and speaking are the most difficult while the most important. The findings of this study are consistent with the findings of the former researchers, that is, mobile micro-learning are effective but it also has its own challenges. In this study, the author combines mobile microlearning with English listening and speaking, which is a new researching field.

In designing or selecting the micro-video or micro-audio materials, the teacher should take these factors into consideration, such as teaching purposes, students’ characteristics, students' ability and their knowledge structure.

Limitations of this study are that only samples of two schools were discussed, and the research subjects are sophomores who have already got a certain period of training in English listening and speaking. In the future, more research can be done among first-year college students to help them improve English listening and speaking quickly.

\section{Conclusions}

A variety of mobile micro-learning tools have been used in the field of education, which benefit learners, teachers, schools and society (based on mobile micro-Learning Business English Training Discussion on the relevance of Modern Enterprise Education 2012.11). With its vividness, it has not only provoked the students' interests in English listening and speaking, but also stimulated the enthusiasm of students. But making or selecting micro-video and micro-audio learning materials should follow these principles:

1) Relevance of learning contents

As a practical form of informal learning, the contents of mobile micro-learning should be suitable for learners and be relevant to the students' real-life.

2) Minimizing the learning contents

Considering the regularity and characteristics of students' learning and the characteristics of micro-learning, learning contents should be made according to one language point which involves a short time of studying. In addition, the learning contents in minimized form can be accepted by learners more easily. Because the learners can be easily distracted in the process of mobile micro-learning, a large amount of knowledge is supposed to de divided into a lot of fragments.

3) Independence and relevance of learning contents

According to the features of mobile micro-learning, the learning contents should be an independent part with a learning goal to be achieved in a very short period of time, so that learners will have a sense of accomplishment. Moreover, each fragments of the knowledge can be connected in the language system. Eventually, an invisible and constant structure can be formed in the process of learning.

4) The attraction of learning contents

During the process of mobile micro-learning, learner's attention is highly dispersed, and learners can not be expected to have a strong motivation and interest. Based on the learning environment and the needs of learners, the design of learning contents should also be noted: first, the theme must be interesting and able to meet the actual needs of learners; second, the form of contents can be organized as games. Entertainment and enjoyment are perfect for learning a language (Wang, 2012: p. 38). For example, listening to a short story or watching an 
educational video-clip; viewing a flashcard to memorize a word, definition or formula; learning some phrases or expressions while playing games.

5) The diversity of learning contents

In order to learn more knowledge in a limited time for students, the design of learning contents should be as various as possible, which can make students learn different kinds of knowledge. Moreover, take the students' age characteristics into consideration, selecting or making diversified learning resources to meet the needs of different learners (Wang, 2012: p. 38).

\section{Acknowledgements}

The paper is under the project of the Application of Mobile Micro-learning in English Viewing. Listening and Speaking (2014J04). All the project members made their contributions to the paper. I also thank all my friends and classmates who work in different universities, which made the investigation possible.

\section{References}

Chen, W. W., \& Li, Y. (2008). The Connotation and Structure of Mobile Micro-learning. Journal of China Educational Technology, No. 9, 16-19.

Hao, A. M., \& Zhang, P. F. (2013). Application of Mobile Micro-Learning Theory in Elementary English Vocabulary Learning. Journal of Electronics World, No. 20, 236-237.

Hu, Y. J. (2015). Influence of the Listening Process Mode on Listening Comprehension and Memory. Journal of Foreign Language World, No.1, 32-39.

Hug, T. (2005). Microlearning: Emerging Concepts, Practices and Technologies after E-learning: Proceedings of Microlearning Conference. Innsbruck: Innsbruck University Press.

Ren, H. F., \& Zhao, J. (2010). Analysis of the Current Research on Mobile learning abroad and in China. Journal of Adult Education, No. 1, 95-96.

Wang, T. M. (2012). Learning Content Design Strategy of Mobile Micro-learning Based on Adult Education. Journal of Adult Education, No. 11, 37-38.

Zhang, H. F., \& Zhu, X. M. (2011). Application of Mobile Micro-Learning in Distance Education. Journal of Modern Educational Technology, No. 4, 75-76. 